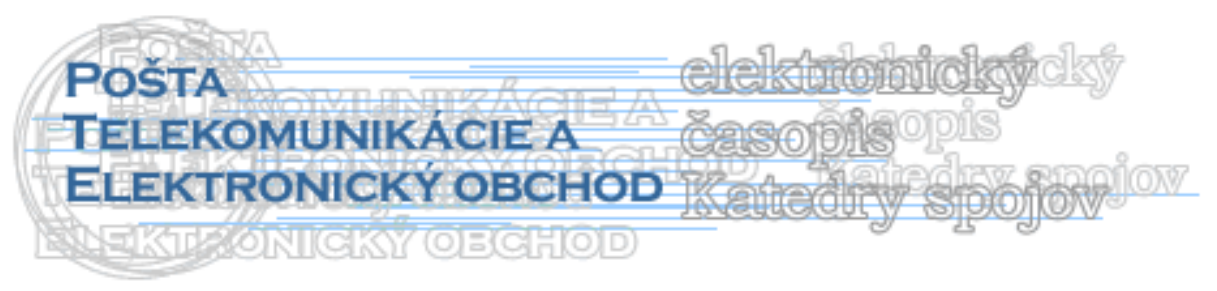

\title{
PREMENA POST-SOCIALISTICKÉHO MESTA ŽILINA
}

\author{
Jakub Cíba* - Mária Rostášová*
}

\section{Úvod}

Mesto ako predmet sociologického skúmania je v odborných kruhoch prítomné už od 19. storočia v Engelsových štúdiách, pričom dôležitost' začala táto téma vel'mi rýchlo naberat' s príchodom tzv. „chicagskej školy“ na začiatku 20. storočia. V súčasnosti tento výrazný a oprávnený záujem o mesto, hoci $\mathrm{v}$ iných perspektívach, pretrváva ako centrálny. V tomto duchu nahliada tento článok na dynamiku súčasného post-socialistického mesta $\mathrm{v}$ kontexte niekol'kých teórií. Ako prípad lokálneho rozvoja, konfrontovaný a porovnaný s teoretickým modelom, bude slúžit' mesto Žilina, ktoré sa za posledné roky ocitá v silnej dynamike lokálnych zmien, ktoré sa odvíjajú práve od globálnych vplyvov, čo ovplyvňuje ako funkcie lokálneho „rastúceho priemyslu“, tak kroky miestnej samosprávy a určuje prejavy lokálneho rozvoja.

\section{Analýza súčasného stavu zameraná na problematiku post-socialistických miest}

$\mathrm{Na}$ Žilinskej univerzite, Fakulte prevádzky a ekonomiky dopravy a spojov je v súčasnosti riešený projekt APVV-0101-10 s názvom Kreatívna ekonomika národohospodárske a regionálne podmienky a stimuly. Problematika rozvoja miest a regiónov je riešená predovšetkým z pohl'adu existencie kreatívnych odvetví, avšak v projekte je venovaná pozornost' aj kondícií miest z pohl'adu ich historického vývoja. Rovnakým smerom je zamerané aj riešenie témy dizertačnej práce, ktorá hl’adá odpoved’ na otázky týkajúce sa práve kreatívnych miest, ktoré majú postsocialistický charakter. Za postsocialistické mesto sa v týchto výskumných projektoch považuje mesto, ktoré prešlo odlišným politickým, sociálnym a najmä ekonomickým vývojom, ako mestá, v ktorých sa štrukturálne zmeny prejavujú rýchlo a výrazne - teda mestá, ktoré by sme mohli označit' za „globálne“. Ďalšie pohl'ady, ktoré pomôžu stanovit' úlohu postsocialistického mesta v globálnej ekonomike, sú klasická idea mesta ako „rastúci priemysel“, rozpracovaná Molotchom (1976) a v súčasnosti rozšírená socio-ekonomická paradigma „spotrebnej spoločnosti““. Zatial’, čo teória „rastúceho priemyslu“ ponúka komplementárny pohl'ad na sociálnu dynamiku mesta, resp. jeho správy, dominancia spotrebnej paradigmy formuje mnoho zaujímavých kontrastov $\mathrm{v}$ centrálnom vzájomnom vzt’ahu globality a lokality. Vo všeobecnosti tak vznikajú štyri línie, ktoré treba pri otázke dopadu sociálnej zmeny na mesto sledovat: široké štrukturálne zmeny, lokálny socio-politický kontext mesta, otázka sociálnych aktérov mesta a taktiež stratégia, ktorú v rámci lokálneho rozvoja uplatňujú. [1]

\footnotetext{
* Ing. Jakub Cíba, Žilinská univerzita v Žiline, Fakulta Prevádzky a ekonomiky dopravy a spojov, Katedra spojov, Univerzitná 1, 01026 Žilina, tel. č.: 041/513 3144, e-mail: jakub.ciba@ fpedas.uniza.sk * prof. Ing. Mária Rostášová, PhD spojov, Katedra spojov, Univerzitná 1, 01026 Žilina, tel. č.: 041/513 3109, e-mail: Maria.Rostasova@fpedas.uniza.sk
} 
Postsocialistické mesto sa premieňa pod vplyvom štrukturálnych zmien v spoločnosti. Dôležité je najprv si vymedzit', čo tento pojem vlastne v sebe zahŕňa a ktorými špecifickými vlastnost'ami sa vyznačuje. Už samotné pomenovanie odkazuje na typ mesta, ktoré prešlo dramatickými zmenami po zlomovom roku 1989. Inak povedané, mestské prostredie formované pod predošlým systémom je adaptované a pretvárané na nové podmienky, ktoré sú dané politickým, ekonomickým a kultúrnym prechodom ku kapitalistickej spoločnosti. [2]

Postsocialistické mesto teda premieňa pozostatky minulého politického režimu. Tieto zmeny súvisia s výraznou premenou štátneho zriadenia, s ciel'om „pridat' sa“ ku kapitalistickému prúdu. Postsocialistické mesto prirodzene nadväzuje na socializmus a zachováva si niektoré typické inherentné znaky a zároveň sa vyvíja v kapitalizme. Proces transformácie postsocialistického mesta teda nie je ukončený, čo zdôrazňuje význam sociálnej zmeny, ktorá naň dopadá a ukazuje, že postsocialistické mesto má vysoký transformačný potenciál. Taktiež je dôležité si uvedomit', že geografická oblast', ktorá spadala v druhej polovici 20. storočia pod vplyv socializmu, je v súčasnosti rozdelená na vel'ké množstvo jednotiek, ktoré podliehajú inému vývoju a sú ekonomicky a politicky rôzne orientované. [3]

Postsocialistické mesto teda zd'aleka nie je možné chápat' ako fenomén s jednou líniou vývoja, ale skôr ako „výsledok neukončeného boja medzi odkazom minulosti a tranzíciou“, pretože jeho sociálna a priestorová organizácia naberá rôzne formy, to znamená, že napríklad mestá v Rumunsku, Kazachstane a na Slovensku budú prechádzat' rôznym vývojom. [2]

Ak prijmeme ideu postsocialistického mesta ako mesta, ovplyvneného zároveň minulost'ou a súčasnost'ou, je nutné identifikovat', ktoré typické rysy socialistického mestského rozvoja sa prejavujú najvýznamnejšie. Borén (2007) a Gentile (2007) identifikujú pät' významných vplyvov socialistickej reality na priestorové premeny mesta - ide o ekonomiku centrálneho plánovania, s n̆ou prepojenú sekundárnu ekonomiku, o distribúciu vlastníctva pozemkov, často výrazne v prospech priemyslu, o problematiku obrany štátu a o ideologickú zložku stranickeho vedenia. Zo socio-priestorového hl'adiska môžeme označit' za najvýznamnejší faktor práve systém centrálneho plánovania, kde obmedzená moc miestnej samosprávy výrazne kontrastuje s kapitalistickým spôsobom mestského rozvoja. Dramatický prechod smerom $\mathrm{k}$ trhovej ekonomike umožnil nielen výrazný ústup od mestského plánovania, ale tiež zmenil spôsob, akým jednotlivé lokality sút’ažia o dostupné zdroje. Taktiež platí, že financovanie $\mathrm{v}$ centrálnom systéme uprednostňuje niektoré ekonomické oblasti na úkor iných - v prípade socializmu išlo najmä o podporu t'ažkého priemyslu, a to najmä na úkor služieb, ktoré predstavujú v kapitalistickom systéme jeden $\mathrm{z}$ najdôležitejších ekonomických sektorov. S tým súvisí aj druhý z uvedených piatich dopadov, ktorý má najvýznamnejší dopad na priestor mesta, spôsob alokácie pozemkov a pod. Uprednostňovanému priemyslu boli teda pridel'ované výhodnejšie pozemky ako iným aktérom v boji o pôdu. „Okrem toho, pri absencii trhovej ceny sa od recyklovania pozemkov (teda nahradenia zaostalých spôsobov využitia pôdy ekonomicky výhodnejšími) neúmyselne odradzovalo, zatial' čo dopyt po pôde bol napíňaný alokáciou „greenfields“" na perifériach socialistická verzia regenerácie mestského centra sa začala až do 80-tych rokov, a aj to $\mathrm{v}$ opatrnom tempe. “" [2]

Takéto procesy odôvodňujú výraznú zmenu funkcie mestského centra $\mathrm{v}$ postsocialistickom meste a taktiež vzniku „brownfields” po procesoch deindustrializácie. Tieto priestory sa pritom často nachádzajú v relatívne centrálnej oblasti samotného mesta a sú $\mathrm{v}$ priestore postsocialistického mesta znovu rozvíjané a preklasifikované, prevažne na kancelárie, obchody a luxusnejšie obytné priestory. Taktiež môže dôjst' $\mathrm{k}$ zachovaniu ich priemyselnej funkcie, s prípadnou premenou zamerania výroby, čo zachováva priemysel na rovnakých miestach, ako počas socializmu: „Lokačná distribúcia industriálnych oblastí spred roku 1989 sa v jednotlivých mestách v princípe nezmenila. Dôvodom je najmä to, že nové 
firmy sa rozvíjali na dostupných 'brownfields', pričom investícii do 'greenfields' bolo iba málo. Aj v týchto prípadoch susedili nové priemyselné zóny s pôvodnými.“. [3]

Ak by sme teda mali zosumarizovat' priestorové premeny, vlastné prechodu medzi socialistickým a postsocialistickým mestom, v centre pozornosti je revitalizácia a komercionalizácia mestského centra, silnejšia, rôznorodá suburbanizácia podriadená trhovým podmienkam na rozdiel od plánovania a taktiež pozostatky prevažne industriálnej činnosti. Okrem toho, postsocialistické mesto oplýva aj husto obývanými sídliskami, ktoré nesú potenciál na revitalizáciu, rovnako, ako širokými bulvármi a námestiami, ktoré mali $\mathrm{v}$ socializme najmä politický význam. Pred postsocialistickým mestom stojí, ako už bolo povedané, radikálna zmena. Takáto transformácia je evidentná $\mathrm{v}$ inštitucionálnych štruktúrach, rovnako, ako $\mathrm{v}$ priestorovej perspektíve, ale zároveň platí, že zmena neovplyvňuje všetkých členov spoločnosti rovnako. „Reformy vo všeobecnosti zvýšili životnú úroveň, ale taktiež dali vzniknút' mnohým negatívnym aspektom, ktoré chýbali v socialistických mestách, ako napríklad nezamestnanost' či široká sociálna stratifikácia rôznorodosti.“ Mnohé sociálne skupiny sa dostali do marginalizovanej pozície a reálne nemajú vel'a šancí participovat' na novom systéme - prevažne ide o l'udí s nižšou životnou úrovňou, prípadne etnicky vymedzené skupiny. Tieto skupiny podliehajú sociálnej aj priestorovej izolácii (vytlačení $\mathrm{z}$ revitalizovaného centra smerom $\mathrm{k}$ perifériám) a tak dávajú podmet na vznik spoločenskej polarizácii, kde majetné obytné štvrte kontrastujú $\mathrm{s}$ segregovanými getami. Ponúka sa teda otázka, kto pri správe mesta skutočne rozhoduje a taktiež, pre koho je vlastne postsocialistické mesto „výhodné“. [3]

Naznačený stav, zahrňujúci sociálne nerovnosti, súvisí taktiež so všadeprítomnou zmenou aktérov, ktorí stoja za mestským rozvojom. Je dôležité si uvedomit', že postsocialistické mesto je súčast’ou (relatívne) globálnej kapitalistickej ekonomiky, kde je oslabená moc národného štátu. Ako bolo naznačené, postsocialistické mesto je ovplyvnené nielen globalitou, ale aj lokalitou - teda lokálnymi elitami, snažiacimi sa o mestskú konkurencieschopnost' a o lokalizáciu kapitálu, a globálnymi aktérmi, ktorí jednak oplývajú kapitálom, o ktorý má miestna samospráva záujem, a jednak poskytujú modely správy, ktoré k získaniu tohto kapitálu vedú. [3]

\section{Ciel' príspevku a metódy skúmania}

Príspevok si kladie za ciel' predstavit' čitatel'om situáciu v jednom zo slovenských miest v Žiline, zdokumentovat' jeho postsocialistický vývoj a na základe uvedených skutočností navrhnút' teoretický model rozvoja postsocialistického mesta. Medzi použité metódy skúmania boli zaradené: metóda analýzy, metóda syntézy, metóda dedukcie a indukcie a v neposlednej miere metóda abstrakcie, ktorá predstavuje spôsob vytvárania obrazov a pojmov, ktorý dáva do popredia všeobecné vlastnosti a ich vzájomné vzt'ahy, s využitím pri zúžení celkového rozsahu predmetnej problematiky.

\section{Výsledky práce a diskusia - rozvoj mesta Žiliny vintenciách teoretického modelu rozvoja post-socialistického mesta}

Teoretický koncept post-socialistického urbánneho rozvoja nepredstavuje univerzálne zákonitosti, ktoré budú platit' v každej lokalite. Dialektický princíp lokality a globality bude znamenat', že sa zrejme budú prejavovat' určité globálne trendy, no zároveň sa bude lokálny rozvoj líšit' v závislosti na lokálnych špecifikách.

Práve lokálne špecifiká Žiliny predstavovali určitý rozdiel oproti typickému postsocialistickému mestu, hoci existuje stále mnoho podobností. Na vstupe do post- 
socialistického prechodu mala Žilina relatívne dobrú pozíciu, práve vzhl'adom na výrazný rozvoj počas socializmu, čo ovplyvnilo identitu mesta: „Postsocialistická decentralizácia politickej moci posilňuje úlohu miest, ktoré musia stanovit' a udržiavat' svoju legitimitu u populácie aj externe.".[4] Ako mesto, ktorého najintenzívnejší rozvoj začal až v 19. storočí, mohla Žilina v transformačnom procese rozvíjat' identitu priemyselného a dopravného uzlu, čo predstavuje určitý strategický základ pre miestnu samosprávu a podklad pre cielenie lokálnej výstavby a investícií.

Za dobré podmienky na vstupe do transformačného procesu mohla rozvinutá dopravná infraštruktúra, ktorá si preniesla svoj význam aj do nového obdobia, a taktiež fakt, že počas socializmu došlo k najväčšej demografickej, priestorovej aj ekonomickej expanzii. Vel'mi silnú zhodu s ideálnym typom post-socialistického mesta predstavovala aj výrazne oslabená funkcia mestského centra - to plnilo okrem spotrebnej iba rezidenčnú a marginálne priemyselnú funkciu. Podobne zhodný je aj typický rys post-socialistického mesta, ktoré prezentujú panelové sídliská. Tie obývajú vel'ké percento lokálneho obyvatel'stva.

Proces transformácie, napriek očakávaniam, neznamenal pre Žilinu výrazný pokles priemyselnej produkcie - väčšie závody si zachovali svoju činnost' až do súčasnosti. Deindustrializácia lokality, ktorá $\mathrm{v}$ mnohých prípadoch znamenala ekonomický pokles, sa týkala prevažne menšieho priemyslu. Z tohto dôvodu nevzniklo v priestoroch mesta privel'a nevyužitých industriálnych „brownfields“ (okrem budov závodu Makyta). Je možné polemizovat', či by papierenská firma Tento bola schopná konkurovat' na trhu bez zahraničnej investície (kúpené fínskou spoločnost'ou Metsä Tissue v roku 2006), stále však platí, že produkcia počas prvých rokov transformácie d'alej fungovala. Dôvodom relatívne stabilnej priemyselnej sféry je jej prednost' $\mathrm{v}$ rámci funkcií lokality, ked’že lokálne centrum koncentruje menej správnych a administratívnych funkcií oproti hlavnému mestu. [3]

Pravdepodobne najväčšia zhoda spočíva v prejavoch „rastúceho priemyslu“ a miestnej samosprávy. Nová výstavba, ktorá nasledovala po stabilizácii lokality, presne zapadá do troch typov - industriálne investície, nákupné centrá a nové rezidenčné oblasti - ktoré boli vymedzené ako hlavné priestorové dopady „rastúceho priemyslu“ v spolupráci $\mathrm{S}$ nadnárodným kapitálom. Zlomovú zmenu predstavovala práve industriálna investícia $\mathrm{v}$ podobe automobilky KIA, ktorá definitívne stanovila dynamiku regionálneho rozvoja a má reálne dôsledky aj $\mathrm{v}$ súčasnosti, zvlášt' $\mathrm{v}$ kontexte rozširovania výroby (teda d'alších investícii). Výrazný ekonomický rast tak kontrastuje s relatívnou absenciou demografického rastu (približne 83000 obyvatel'ov v 80 -tych rokoch, 84130 obyvatel'ov k 30.09.2013), čo by potvrdzovalo, že lokálny rast $\mathrm{v}$ súčasnosti nemusí byt' paralelný s rastom demografickým resp. expanzia populácie nemusí byt' nutne „symptómom“ rastu priemyslu, skvalitnenia pracovnej sily, rozvoja komerčných príležitostí a podobne.

V prvom prípade ide o využitie a rozvíjanie lokálnych výhod (rozvinutá doprava a dostupná pracovná sila) na produkciu konkrétneho typu produktu, čo okrem iného, zvyšuje úspech $\mathrm{v}$ sút'aži o investície. Druhý prípad znamená snahu mesta zlepšovat' konkurencieschopnost' pomocou dostupnosti spotreby - tejto forme podnikatel'skej správy chronologicky predchádzal ekonomický rozvoj. Z pozície miestnej samosprávy bol v Žiline úspešne vytvorený ekonomicky dynamický a relatívne bohatý región a zároveň miesto $\mathrm{s}$ dostupnými možnost’ami spotreby a kultúry. Takýto obraz získava mimoriadny význam v rámci marketingu lokality. Mesto musí predovšetkým vyzerat' ako inovatívne, vzrušujúce, kreatívne a bezpečné miesto pre bývanie a návštevu, pre hru a spotrebu. Reprezentácia Žiliny ako dynamického regiónu môže byt', ako bolo vyššie naznačené, použitá na zopakovanie cyklu ekonomického rastu. Zaujímavým prejavom, ktorý poukazuje na špecifickú nerovnost' verejno-súkromného partnerstva $\mathrm{v}$ prospech súkromného sektoru, znamená najnovší vývoj. Predstavenstvo mesta sa, počas predchádzajúceho funkčného obdobia, snažilo zrušit' výstavbu 
nákupného centra Aupark (v podozrení z klientelizmu v rámci predania priestorov Štúrovho námestia počas fungovania primátora Jána Slotu) - neúspešne. V marci roku 2012 bolo mesto (ako právnická osoba) zažalované predstavenstvom Auparku za ušlý zisk v čiastke 17, 6 milióna eur. Potvrdzuje to vyššie predložený vzt’ah o podradenosti verejného sektoru voči súkromnému sektoru, ktorý má tak väčšiu iniciatívu v rámci miestnej samosprávy.

Špeciálny dôraz pri rozvoji Žiliny bol kladený práve na rozvoj spotreby. V meste dochádzalo $\mathrm{k}$ rozvoju spotreby najprv po ekonomickej stabilizácii a následne po dosiahnutí rastu - čiže v dvoch fázach. Zatial', čo prvá fáza znamenala rozvoj spotreby suburbánnych oblastí, druhá fáza predstavuje vel'mi špecifický typ rozvoja vzhl'adom na stav mesta, ked’že rozvoj bol zameraný na jeho samotné centrum. Ak prijmeme ideu mestského centra v postsocialistickom meste ako na málo rozvinutý, strategický priestor, kde dochádza ku stretu záujmov lokálnych aktérov, znamená nárast možností spotreby $\mathrm{v}$ centre určitý spôsob revitalizácie. Výstavba dvoch centrálne umiestnených nákupných centier znamenala okrem rozšírenia možností spotreby aj zmenu vnímania centra mesta (symbolické strhnutie historickej budovy a jej nahradenie centrom spotreby v prípade obchodného centra Mirage), vytvorenie symbolických „,vlajkových lodí“ lokálneho rozvoja a tiež „návrat“ obyvatel'ov do centra, resp. opätovné naplnenie vnútorného priestoru mesta. Taktiež bola takáto výstavba výhodná $\mathrm{z}$ demografického pohl'adu $-\mathrm{v}$ relatívne malom meste ( $\mathrm{v}$ porovnaní napr. so zvyškom Európy) je efektívnejšie spotrebu centralizovat', ako cielit' na jednotlivé mestské oblasti, zvlášt', ak zatial' nie je jasné, aké je priestorové rozdelenie nerovností vzhl'adom na spotrebu.

Premeny rezidenčných oblastí v určitej miere súhlasia s teoretickými predpokladmi. Reálne prebieha výstavba nových bytových kapacít, prevažne ako renovácia a rozširovanie sídlisk alebo na dostupných miestach v širšom centre mesta (napr. Bôrik). Paralelne s tým prebieha určitý nárast rezidenčnej suburbanizácie vid’. Obrázok 1.. (v okrajových mestských častiach, ako napr. Trnové, Bytčica alebo sídlisko Hájik). Proces gentrifikácie, ktorý by sa mal diat' prevažne vo vnútornom meste, nie je príliš viditel'ný, resp. nie sú vytvárané viditel'né, ucelené gentrifikované priestory. Gentrifikácia je považovaná za súbor lokálnych sociálno-kultúrnych zmien, ktoré sú dôsledkom toho, že bohatší jednotlivci nakupujú nehnutel'nosti na bývanie $\mathrm{v}$ dosial' menej prosperujúcich spoločenstvách. V nadväznosti na gentrifikáciu rastie priemerný príjem a klesá priemerná vel'kost' rodiny $\mathrm{v}$ spoločenstve, čo môže viest' k vytlačeniu nízkopríjmových vrstiev obyvatel'stva (z dôvodu zvýšeného nájomného, vyššej ceny domov a vyššej dane z vlastníctva). Tento typ populačnej zmeny znižuje priemyselné využitie pôdy, ktoré ustupuje využitiu pre obchod a bývanie. Okrem toho sa do skôr zanedbaných oblastí st'ahujú nové firmy zamerané na bohatších zákazníkov, čo d'alej znižuje dostupnost' služieb pre menej majetných obyvatel'ov mesta. Relatívne menej sa v rámci výstavby tiež vyskytujú kancelárske priestory (väčšina priestorov existuje v pôvodnej socialistickej výstavbe), čo je pravdepodobne dané dôrazom lokálneho rozvoja skôr na technologicky pokročilú a efektívnu produkciu, ako na iné potenciálne funkcie, vyhradené skôr správnemu centru.

Vel'mi špecifická sociálna zmena sa udiala pri výstavbe automobilky KIA. Migrácia vyšších vrstiev s manažérskymi pozíciami do priestoru lokality znamenala vytvorenie novej etnicky aj príjmovo - odlišnej sociálnej skupiny. Zaujímavé je, že táto skupina sa takmer okamžite priestorovo segregovala od lokálnej populácie, čo by mohlo znamenat' prejav posilňovania sociálnej polarizácie. Okrem toho sa nedošlo $\mathrm{v}$ rámci procesu priestorového rozloženia sociálnych nerovností k privel'kým zmenám, kde najmenej majetné sociálne vrstvy obývajú rovnaké časti vnútorného mesta vid’ Obrázok 1. (na západ od centra mesta, v blízkosti železničnej aj cestnej komunikácie a tiež zóny priemyslu a logistiky) - zaujímavé je, že táto oblast' sa nachádza na opačnej strane od centra miesta, ako väčšina novej výstavby 
Otázkou ostáva, do akej miery bude postupom času komerčný priestor centra mesta znamenat' vytvorenie bariér medzi jednotlivými skupinami.

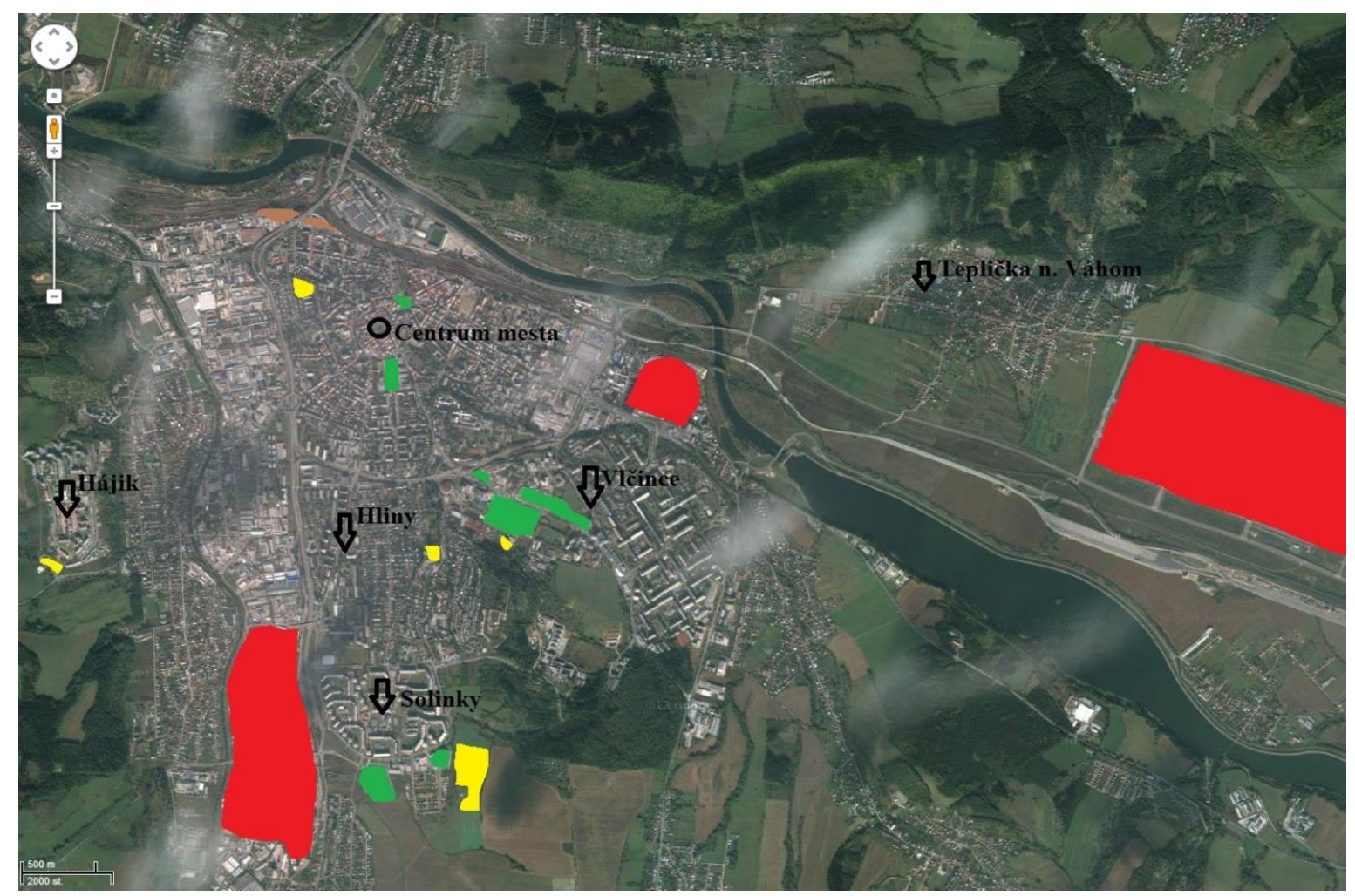

Obrázok 1. Mapa Žiliny s rozlíšenými funkčnými zónami (Zdroj: autor)

Zelené zóny: Zóny spotreby (zhora nadol: obchodné centrum Mirage; obchodné centrum Aupark; spotrebná zóna na okraji Vlčiniec - obchodné centrum Atrium a centrá Lidl, Kaufland, Baumax, Europalace; spotrebná zóna na Solinkách obchodné centrá Max a Metro).

Žlté zóny: Nová bytová výstavba (nezahŕňa rekonštruovaný bytový fond a rozširovanie sídlisk).

Červené zóny: Priemyselné oblasti (zl’ava doprava: pôvodná industriálna oblast', papierne Tento-Metsä tissue, automobilový závod KIA).

Hnedá zóna: Oblast' sociálne vylúčených skupín obyvatel'stva v okolí Bratislavskej ulice.

Celkovo by sa na základe zistených skutočností mohlo povedat', že rozvoj Žiliny a okolitého regiónu je skôr súhlasnýs teoretickým modelom rozvoja post-socialistického mesta. Po stabilizácii v novom ekonomickom systéme dosiahla lokalita významný úspech v podobe lokalizácie nadnárodného kapitálu. Práve tento úspech, stelesnený v automobilovom závode KIA, predstavuje zlomový bod a určenie smerov d'alšieho rozvoja. Znamenalo by to, že lokálny rozvoj je pri post-socialistickom meste, do významnej miery závislý práve od lokalizácie nadnárodného kapitálu, ktorý legitimizuje d’alšie kroky miestnej samosprávy a rastovej koalície.

\section{Záver}

Post-socialistické mesto je charakterizované dynamickým procesom transformácie. Žilina, s prejavmi „rastúceho priemyslu“ a jednaním miestnej samosprávy, predstavuje jednu z lokalít, kde tento proces spôsobil výraznejšie premeny ekonomického usporiadania premeny, ktoré následne ovplyvňujú urbanistické aspekty mesta, konštruujú identitu 
lokálneho obyvatel'a a menia spôsob zažívania a percepcie mesta. Idea rastu, podl'a interpretácie výsledkov výskumných aktivít, stále ostáva dominantným ciel'om nielen konkrétnej lokality, ale modelu post-socialistického mesta všeobecne. Tranformačné procesy neustále pretrvávajú a je možné očakávat' d’alšie zmeny v kontexte lokálneho rozvoja. Otázkou zostáva, kedy nastane reinkorporačná fáza a socialistická minulost' bude integrovaná do nového modelu mesta.

\section{Literatúra}

[1] Mesto ako „rastúci priemysel“ [online] [cit. 2013-08-10] Dostupné na internete: <http://www.jstor.org/discover/10.2307/2777096?uid=3739024\&uid=2\&uid=4\&sid=211 02549642357>

[2] Postsocialistické mestá [online] [cit. 2013-03-03] Dostupné na internete: <http://www.unipo.sk/public/media/16170/S\%C3\%BDkora_2009_Postsocialist\%20Cities.pdf>

[3] Kultúrna krajina postsocialistických miest [online] [cit. 2013-03-03] Dostupné na internete: 〈http://hsozkult.geschichte.hu-berlin.de/rezensionen/2009-1-107>

[4] YOUNG, C., KACZMAREK, S.: The Socialist Past and Postsocialist Urban Identity in Central and Eastern Europe

\section{Grantová podpora:}

Projekt APVV-0101-10 - Kreatívna ekonomika - národohospodárske a regionálne podmienky a stimuly. 